\title{
Effects of Replacing Soybean Meal with Crassocephalum crepidioides leaf Meal on Growth, Nutrient Utilisation and Whole Body Composition of Labeo rohita Fingerlings
}

\author{
Khinlak Gangmei*, Kamal Kant Jain, Narottam Prasad Sahu, \\ Ashutosh Dharmendra Deo and Kundan Kumar
}

Central Institute of Fisheries Education, Versova, Mumbai - 400 06, India

*Corresponding author

\section{Keywords}

Crassocephalum

crepidioides leaf meal

(CLM), Labeo rohita,

Indigenous knowledge,

Growth, Nutrient

utilisation

Article Info

Accepted:

06 August 2018

Available Online:

10 September 2018

\section{A B S T R A C T}

The present study was conducted to evaluate the effect of soybean meal replacement with Crassocephalum crepidioides leaf meal (CLM) on growth, nutrient utilisation and whole body composition of Labeorohita fingerlings. A C. crepidioides leaf meal (CLM) was prepared by removing antinutritional factors through indigenous processing technique. The antinutritional factors of the processed CLM were found to decrease substantially, and the in vitro digestibility of the CLM was $75.31 \%$. The nutritional potential of CLM in the diets of Labeorohita fingerlings (initial average weight $5.62 \pm 0.07 \mathrm{~g}$ ) were assessed in a 60 days feeding trial. Five isonitrogenous $\left(305.0 \pm 0.08 \mathrm{~g} \mathrm{Kg}^{-1}\right)$ and isocaloric $\left(16.74 \pm 0.02 \mathrm{MJ} \mathrm{Kg}^{-1}\right)$ experimental diets were formulated with a graded level of CLM, i.e. $0 \%, 5 \%, 10 \%$ or $15 \%$ in replacement for soybean meal, and designated as control, CLM5, CLM10, CLM15 respectively were fed with their respective diets to satiation twice daily at 10:00h and 18:00h. At the end of the experiment, growth performance and nutrient utilization indices such as individual weight gain (99.30-135.10\%), specific growth rate (1.15-1.42\%), feed conversion ratio (1.76-2.26), protein efficiency ratio (1.44-1.87) were not significantly ( $p>0.05)$ affected by the dietary treatments irrespective of inclusion levels of CLM. Hepatosomatic index (1.04-1.31), intestinal somatic index (4.19-4.65), survival (100\%) and whole body composition of the fish among various dietary groups did not vary significantly $(p>0.05)$. Thus, this study revealed that CLM is a promising alternative source of protein which could replace soybean meal up to $15 \%$ in the diets of $L$. rohita fingerlings without any adverse effects on growth, nutrient utilisation, whole body composition.

\section{Introduction}

Over the past three decades, global aquaculture production expanded at an average annual rate of more than $8 \%$, from 5.2 million tons in 1981 to 62.7 million tons in 2011. Aquaculture's contribution to total food fish supply grew from $9 \%$ in 1980 to $48 \%$ in 2011 (FAO, 2013). Hence, a projected model of aquaculture production possible to increase from 28.6 million tons in 1997 up to 53.6 million tons by 2020 where developing countries would be responsible for $79 \%$ of world food fish production, with $77 \%$ of 
global fish consumption. The assessed number of fish farmers also grew from 3.9 million in 1990 to 16.6 million in 2010. The fast and massive growth of aquaculture production has contributed significantly to the increased production of species (World Bank 2013). However, on the other side major fish feed ingredients such as soybean meal is one of the most widely used plant protein source in aqua feed production for many fish species including Labeo rohita (Storebakken et al., 2000). Its limited availability and competition with feed production of livestock and poultry led to a rise in the price of common feed ingredients (Coffey et al., 2016). Hence, there is an urgent need for alternative economically viable and sustainable aqua feed production to soybean meal.

In this regard, one of the nutritious plant, Crassocephalum crepidioides contains high protein value $(27 \%)$ with all essential amino acids can be considered as an alternative source of protein (Dairo and Adanlawo, 2007). The C.crepidioides plant is locally available in North-East region of India (Worlds 12 mega biodiversity-rich zones), especially in Manipur. It is perennial herbs (Heim, 2015) and highly adaptive to harsh environments and resistance against diseases. The Crassocephalum crepidioides or fireweed belongs to Asteraceae family and commonly called as Terapaibee in Manipuri (Rajkumari et al., 2013). A C.crepidioides is wild and underutilised vegetables which is a good source of micronutrients and natural antioxidants ( $\mathrm{Ng}$ et al., 2012). It is the rich source of minerals such as sodium, potassium, phosphorus, magnesium, calcium, iron, Manganese and Copper (Adjatin et al., 2013).

North-east region of India is the store house of indigenous knowledge (Hanglem et al., 2017). Different varieties unexplored wild of edible plants are utilised through indigenous knowledge of food preparation and preservation such as boiling, heat treatment and drying by the tribal people of Manipur (Gangte et al., 2013). The contents of antinutritional factors such as phytate and saponin in C. crepidioidesis even lesser than soybean meal. Nevertheless, cyanide contents is high in C.crepidioides (Etong and Abbah 2014, Hanssen 2003, Peisker, 2001). Cyanide contents in Crassocephalum crepidioides can be detrimental to the culture organism. So, in order to remove antinutritional factors for utilization Crassocephalum crepidioides leaf meal (CLM) in fish feed formulation indigenous technical knowledge (ITK) is used. Till date, no single study is available on the use of CLM in fish and livestock. Hence, with this backdrop, CLM was prepared through indigenous processing techniques and fed to Labeo rohita (rohu) to assess the potential utilization for aqua feed production. Due to high consumer preference, Labeo rohita is the most popular and widely cultured freshwater fish in South-east Asia. Thus, the present study was conducted to examine the nutritional potential of Crassocephalum crepidioides leaf meal (CLM) and its effect on growth performance, nutrient utilization and whole body composition of Labeo rohita fingerlings.

\section{Materials and Methods}

\section{Identification and collection of herbs}

The herbs were identified according to the report of Thokchom et al., 2015 who described that Crassocephalum crepidioides $\mathrm{S}$ Moore is known by local name as Terapaibee, which belongs to Asteraceae family. It is wild herb found in Manipur and north east region of India. Rajkumari et al., (2013) also reported that C.crepidioides is an edible plant species used by tribal people of Manipur for traditional medicine and other ethnobotanical purposes. The herb Crassocephalum crepidioides was procured from Zimthiang 
village, Loktak Project, Manipur. The herb was packed in a carton box and brought to Fish Nutrition and Biochemistry Laboratory of the Central Institute of Fisheries Education (CIFE), Mumbai.

\section{Processing/ detoxification of Crassocephalum crepidioides leaf meal (CLM)}

Steps of CLM production and its detoxification are shown in Figure 1.

\section{Steam blanching}

Steam blanching was done by the modified method of Indriasari et al., (2016). The fresh Crassocephalum crepidioides leaves were tied in a dry muslin cloth and placed in stainless steel cylinder with perforated side walls. The C.crepidioides leaves were steam blanched at $105^{\circ} \mathrm{C}$ for 10 minutes in auto-clave. After the blanching, the steamed C.crepidioides leaves were removed from auto-clave and cool down quickly to drastically reduce the temperature of the leaves in a very short duration of time and then spread into a perforated tray for air drying.

\section{Squeezed/pressure}

Squeezing of leaves was done by indigenous technical knowledge (ITK) as described by Tamang 2009. This ITK concept of pressurizing and squeezing is to remove antinutritional factors through reduction of moisture content in the leaf. The Crassocephalum crepidioides leaves were squeezed to remove excess water and pressed in a wide flat surface vessel.

\section{Drying}

Squeezed Crassocephalum crepidioides leaves were then transferred into hot air oven and dried at $60^{\circ} \mathrm{C}$.

\section{Shredding and grinding}

Dried C. crepidioides leaves were chopped into smaller pieces and ground into Crassocephalum crepidioides leaf meal (CLM) in a laboratory grinder and sieved into fine meal to be used for feed formulation.

\section{Determination of anti-nutritional factors}

\section{Cyanide}

Cyanide was estimated by alkaline titration method of AOAC (1975). Around $150 \mathrm{ml}$ of sample was steam-distilled into a solution of $\mathrm{NaOH}$. The distillate was treated with dilute $\mathrm{KI}$ solution and followed by titration against $0.02 \mathrm{~N} \mathrm{AgNO}_{3}$ solution. The endpoint was obtained when there was a change from clear to a faint but permanent turbid solution. The hydrogen cyanide content was calculated by taking $1 \mathrm{ml}$ of $0.02 \mathrm{~N} \mathrm{AgNO}_{3}$ as equivalent to $1.08 \mathrm{mg}$ Hydrogen Cyanide (HCN).

\section{Saponin}

Saponin estimation was carried out by following a gravimetric method of AOAC (1984) employing the use of a Soxhlet extractor and sequential extraction of two different organic solvents with acetone and methanol. At the end of extraction, the flask used in the extraction process was oven dried, cool in a desiccator and then weigh. Saponin content was expressed in $\mathrm{g} / \mathrm{kg}$.

\section{Tanin}

Tannin was estimated as described by Makkar et al., (1993). Around $50 \mu \mathrm{L}$ of tannins extract was taken in a test tube, and the volume made up to $1.0 \mathrm{ml}$ with distilled water, and then Folin Ciocalteu solution of $0.5 \mathrm{ml}$ was added and mixed. After mixing, $2.5 \mathrm{ml} 20 \%$ sodium carbonate solution was added and again mixed and kept for $40 \mathrm{~min}$ at room temperature. 
Optical density was taken at $725 \mathrm{~nm}$ in spectrophotometer and results were expressed as tannic acid equivalents.

\section{Phytic acid}

Phytic acid estimation was carried out following the spectrophotometric procedure of Vaintraub and Lapteva (1998). Trichloroacetic acid (3\% TCA) solution $50 \mathrm{~mL}$ was taken into $500 \mathrm{mg}$ of sample in a flask and shaken for 30 min followed by centrifugation at $3000 \mathrm{~g}$ for $10 \mathrm{~min}$ and $4 \mathrm{ml}$ of ferric chloride solution was added rapidly to an aliquot of $10 \mathrm{~mL}$. This was kept in a water bath at boiling temperature and centrifuged again. After washing with 3\% TCA, the precipitate was dispersed in a distilled water and three $\mathrm{mL}$ of $1.5 \mathrm{~N} \mathrm{NaOH}$. The solution was made up to $30 \mathrm{~mL}$ and filtered through a Whatman No. 2 filter paper, and the precipitate was dissolved in a $40 \mathrm{~mL}$ hot $3.2 \mathrm{~N}$ nitric acid. After cooling, the volume was made to $100 \mathrm{~mL}$ with distilled water. From this, $5 \mathrm{~mL}$ aliquot was made to $100 \mathrm{~mL}$ using $20 \mathrm{~mL}$ of $1.5 \mathrm{M} \mathrm{KSCN}$ and distilled water. The reading was measured at $480 \mathrm{~nm}$ using a UV-visible spectrophotometer (Shimadzu, UV-1800, Kyoto, Japan), and a blank with each sample was run. Phytic acid was expressed as percentphytic acid equivalent.

\section{Oxalate}

Oxalate was estimated according to the titration method of Day, and Underwood, 1986. $1 \mathrm{~g}$ of a sample was added in $75 \mathrm{ml} \mathrm{3M}$ $\mathrm{H} 2 \mathrm{SO} 4$ and stirred for $1 \mathrm{hr}$ with a magnetic stirrer. This was filtered using a Whatman No 1 filter paper. $25 \mathrm{ml}$ of the filtrate was titrated against warm $0.05 \mathrm{M} \mathrm{KMnO} 4$ solution until a faint pink colour persisted for at least $30 \mathrm{sec}$. The oxalate content was determined by taking $1 \mathrm{ml}$ of $0.05 \mathrm{~m} \mathrm{KMnO} 4$ as equivalent to $2.2 \mathrm{mg}$ oxalate (Chinma, \& Igyor 2007; Ihekoronye and Ngoddy 1985).

\section{In vitro protein digestibility}

In vitro protein digestibility study was done as per the procedure of Ali et al., (2009). A fresh tissue of the alimentary canal was homogenized under cold condition and diluted with distilled water $(1: 10 \mathrm{w} / \mathrm{v})$. Enzyme was extracted by centrifuging it at $12000 \mathrm{rpm}$ for $15 \mathrm{~min}$ at $4{ }^{\circ} \mathrm{C}$. An equivalent amount of finely ground $C$. crepidioides $1 \mathrm{~m}$ that provided $160 \mathrm{mg}$ of crude protein was weighed and mixed with $20 \mathrm{~mL}$ of distilled water and $2 \mathrm{~mL}$ of the enzyme to obtain $8 \mathrm{mg}$ crude protein per millilitre and the $\mathrm{pH}$ was adjusted to 8 (Eutop pH tutor, Thermo Fisher Scientific, Singapore). The $\mathrm{pH}$ drop was recorded at every minute interval for $10 \mathrm{~min}$, and casein was used as the reference protein. Relative Protein Digestibility was estimated using the following formula

Relative Protein Digestibility (RPD \%) $=(-$ $\Delta \mathrm{pH}$ of ingredients/- $\Delta \mathrm{pH}$ of casein) $\mathrm{x} 100$.

\section{Proximate analysis}

Proximate analysis of Crassocephalum crepidioides leaf meal (CLM) and feed (on dry matter basis) and muscle tissue (on wet weight basis) were performed as per the standard method of AOAC (1995). Digestible energy was calculated using the following formula:

Digestible energy (DE, $\left.\mathrm{MJ} \mathrm{Kg}^{-1}\right):[16.74 \times \mathrm{CP}$ $\left(\mathrm{g} \mathrm{Kg}^{-1}\right)+37.66 \times \mathrm{EE}\left(\mathrm{g} \mathrm{Kg}^{-1}\right)+16.74 \times \mathrm{TC}(\mathrm{g}$ $\left.\left.\mathrm{Kg}^{-1}\right)\right] / 1000$ (Harvel 1976)

\section{Experimental diets}

The experimental diets were divided into four groups which were isonitrogenous $\left(305.0 \pm 0.08 \mathrm{~g} \quad \mathrm{Kg}^{-1}\right)$ and isocaloric $\left(16.74 \pm 0.02 \mathrm{MJ} \mathrm{Kg}^{-1}\right)$. The soybean meal was replaced at $0 \%, 5 \%, 10 \%$ or $15 \%$ with Crassocephalum crepidioides leaf meal 
(CLM) which was designated as Control, CLM5, CLM10, CLM15, respectively (Table $1)$. The ingredients were ground and mixed thoroughly to form a homogenous blend followed by addition of vitamin-minerals mixture, oil and water to form a dough. The prepared dough was passed through a pelletizer using $2 \mathrm{~mm}$ die and the pellets were air dried, and stored at $-20{ }^{\circ} \mathrm{C}$ until further use.

\section{Acclimatisation of fish and experimental setup}

Fingerlings of Indian major carp, Labeo rohita ranging between $5.27 \mathrm{~g}$ and $6.13 \mathrm{~g}$ body weight were procured from Arey fish farm, Goregaon, Mumbai, India.

The fishes were transported in a big circular container $(500 \mathrm{~L})$ with sufficient aeration to the wet laboratory of Central Institute of Fisheries Education (CIFE). The fishes were given a mild salt dip treatment $\left(20 \mathrm{~g} \mathrm{~L}^{-1}\right)$ for 2 min before transferring to another circular tank (1000 L). The stock was acclimatized under aerated conditions in the same circular tank for a period of 15 days.

The experiment was conducted in 12 plastic rectangular tubs (75L capacity) covered with perforated lids previously treated and cleaned with potassium permanganate (KMnO4) solution.

One hundred and forty-four fingerlings were randomly distributed in four distinct experimental groups. The experiment was conducted for a period of 60 days and fishes were fed at $3 \%$ of the body weight. The daily amount of feed was section into two equal parts and was fed at 10:00 and 18:00h using the respective experimental diets. Uneaten feed, together with feces, was carefully siphoned out manually. Water quality was monitored throughout the experiment (APHA 1998).

\section{Fish sampling}

At the end of feeding trial the fishes were starved overnight and then weighed for calculating the growth performance and nutrient utilization parameters such as weight gain (\%), specific growth rate (SGR), feed conversion ratio (FCR), protein efficiency ratio (PER). Fishes were sampled from each replicate and anaesthetized, tissues of different organs liver and intestine were dissected out. Body indices parameters like hepato-somatic index and intestine-somatic index were calculated. For proximate analysis, all the dissected fishes from every replicate were collected, weighed and kept in pre-weighed Petri plates.

\section{Calculations}

Following parameters related to growth and nutrient utilization were calculated using standard formula.

Weight gain $(\%)=[($ final weight-initial weight)/initial weight] $\mathrm{x} 100$; specific growth rate $(\mathrm{SGR}, \%)=100 \times$ (ln final body weight-ln initial body weight)/experimental duration in days; feed conversion ratio $(\mathrm{FCR})=\{$ feed consumption ( $\mathrm{g}$ on dry weight basis)/body weight gain (g on wet weight basis) \}; protein efficiency ratio $(\mathrm{PER})=\{$ net weight gain $(\mathrm{g}$ on wet weight basis)/protein fed ( $\mathrm{g}$ on dry matter basis) $\}$ and the survival $(\%)=[$ (Total number of fish harvested/ total number of fish stocked) $x$ 100]. Hepatosomatic index (HSI) and intestinal somatic index (ISI) were calculated using the following formula:

$$
\operatorname{HSI}(\%)=\frac{\text { Weight of liver }(\mathrm{g})}{\text { Weight of fish }(\mathrm{g})}
$$

The gastrointestinal tract of different treatment groups were recorded and the gastrointestinal index was calculated as follows 
$\operatorname{ISI}(\%)=\frac{\text { Weight of intestine }(\mathrm{g})}{\text { Weight of fish }(\mathrm{g})}$

\section{Statistical analysis}

Data were statistically analyzed by SPSS package version 16.0 which were subjected to one way ANOVA and Duncan's multiple range test to determine the significant differences between the means. Comparisons were made at the $5 \%$ probability level.

\section{Results and Discussion}

Proximate composition of Crassocephalum crepidioides leaf meal (CLM) and experimental diet

The results of proximate composition of Crassocephalum crepidioides leaf meal (CLM) and the experimental diet are presented in Table 2. The proximate composition of C.crepidioides leaf meal (CLM) viz, crude protein $\left(\mathrm{g} \mathrm{Kg}^{-1}\right)$ ranges from 268.9 to 276.3 , crude lipid $\left(\mathrm{g} \mathrm{Kg}^{-1}\right)$ ranges from 26.5 to 30.4 , ash $\left(\mathrm{g} \mathrm{Kg}^{-1}\right)$ level varies from 186.4 to 194.8 , and digestible energy ( $\mathrm{MJ} \mathrm{Kg}^{-1}$ ) ranges from 14.03-14.24. On the other side, the proximate composition of the experimental diet showed crude protein $\left(\mathrm{g} \mathrm{Kg}^{-1}\right)$ ranges between 301.6 to 310.2 , crude lipid $\left(\mathrm{g} \mathrm{Kg}^{-1}\right)$ varies from 61.8-72.4, nitrogen-free extract $\left(\mathrm{g} \mathrm{Kg}^{-1}\right)$ varies from 467.8-480.3, crude fibre $\left(\mathrm{g} \mathrm{Kg}^{-1}\right)$ ranges from 62.8-75.3, ash $\left(\mathrm{g} \mathrm{Kg}^{-1}\right)$ ranges from 80.5-89.6, digestible energy ( $\mathrm{MJ} \mathrm{Kg}^{-1}$ ) levels was in between 16.60-16.82.

Antinutritional factors of unprocessed $C$. crepidioides leaf meal and processed $C$. crepidioides leaf meal (CLM)

The results of antinutritional factors of unprocessed $C$. crepidioides leaf meal and processed C. crepidioides leaf meal (CLM) are presented in Table 3. Antinutritional factors present in C. crepidioides leaf meal are cyanide, phytic acid, saponin, oxalate and tannin. Cyanide was removed to maximum extend from $11.85 \mathrm{mg} \mathrm{HCN} \mathrm{Kg}$ in unprocessed $C$. crepidioides leaf meal to 2.83 $\mathrm{mg} \mathrm{HCN} \mathrm{Kg}$ in processed C. crepidioides leaf meal (CLM).

\section{In vitro protein digestibility and water quality parameters}

The result of protein digestibility of Crassocephalum crepidioides leaf meal (CLM) in in vitro study was found to be $75.31 \%$.

Water quality parameters are given in Table 4. The water quality parameters such as temperature was $24.8-28.5^{\circ} \mathrm{C}$, dissolve oxygen 5.6-7.1 $\mathrm{mg} / \mathrm{L}, \mathrm{pH}$ 7.2-8.3 and ammonia 0.01$0.06 \mathrm{mg} / \mathrm{L}$.

Growth performance, nutrient utilisation, hepatosomatic index (HSI), intestinal somatic Index (ISI) and survival

Studies on growth and nutrient utilisation of the fish were exhibited in terms of the weight gain (\%), SGR, FCR, PER, HSI and ISI. Higher weight gain, SGR, PER and lower FCR were found in the control group, CLM5 and CLM10 compare to CLM5.

However weight gain (\%), SGR, FCR, PER, HIS, ISI and survival of the fish among different experimental groups were not affected significantly $(p>0.05)$ through the feeding of CLM (Table 5).

\section{Whole body composition of the fish}

Whole body composition was presented in Table 6. It was observed that feeding of CLM did not show any significant trend in the whole body composition of fish in the experimental groups. 
Fig.1 Process of Crassocephalum crepidioides leaf meal production and its detoxification

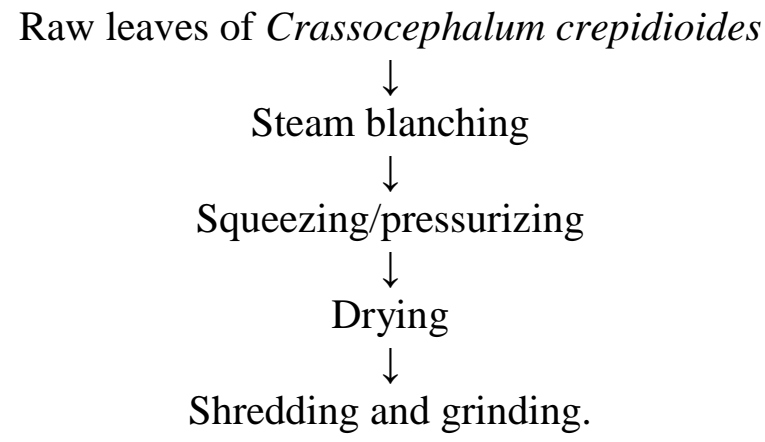

Table.1 Composition of the test diets used during experimental feeding trial $\left(\mathrm{g} \mathrm{Kg}^{-1}\right)$
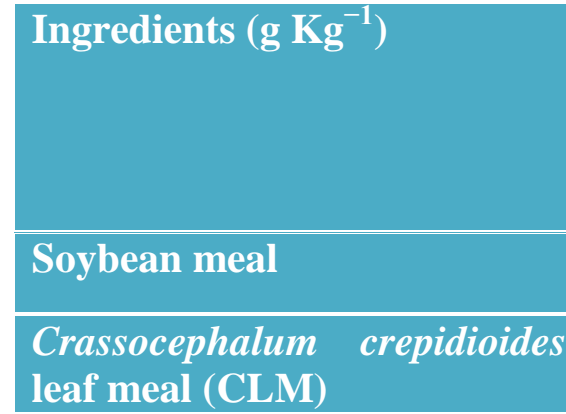

Fish meal

Mustard oil cake

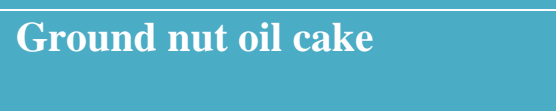

Wheat flour

Rice bran

Fish oil

Sunflower oil

Vitamin/mineral mix

Carboxymethyl cellulose

\section{Butylatedhydroxytoluene}

\begin{tabular}{|c|c|c|c|}
\hline \multicolumn{4}{|c|}{ Treatments } \\
\hline Control & CLM5 & CLM10 & CLM15 \\
\hline 210 & 200 & 189 & 178.5 \\
\hline 0 & 10.5 & 21 & 31.5 \\
\hline 60 & 60 & 60 & 160 \\
\hline 169.7 & 170 & 170 & 170 \\
\hline 200 & 210 & 210 & 220 \\
\hline 150 & 150 & 150 & 150 \\
\hline 118.3 & 107.5 & 108 & 98 \\
\hline 20 & 20 & 20 & 20 \\
\hline 40 & 40 & 40 & 40 \\
\hline 20 & 20 & 20 & 20 \\
\hline 10 & 10 & 10 & 10 \\
\hline 2 & 2 & 2 & 2 \\
\hline & & & \\
\hline
\end{tabular}

Composition of vitamin mineral mix (PREEMIX PLUS, Himedia, India) (quantity/2.5kg), Vitamin A, 55,00,000 IU; Vitamin $\mathrm{D}_{3}, 11,00,000 \mathrm{IU}$; Vitamin $\mathrm{B}_{2}, 2,000 \mathrm{mg}$; Vitamin E, $750 \mathrm{mg}$; Vitamin K, 1,000 mg; Vitamin $\mathrm{B}_{6}, 1,000 \mathrm{mg}$; Vitamin $\mathrm{B}_{12}, 6 \mathrm{mcg}$; Calcium Pantothenate, 2,500 mg; Nicotinamide, $10 \mathrm{~g}$; Choline Chloride, $150 \mathrm{~g}$; Mn, 27,000 $\mathrm{mg}$; I, 1,000 mg; Fe, 7,500 mg; Zn, 5,000 mg; Cu, 2,000 mg; Co, 450 L- lysine, $10 \mathrm{~g}$; DL- Methionine, $10 \mathrm{~g}$; Selenium, $50 \mathrm{ppm}$ 
Table.2 Proximate composition ( $\mathrm{g} \mathrm{Kg}^{-1}$ dry matter basis) of Crassocephalum crepidioides leaf meal (CLM) and experimental diets

\begin{tabular}{|c|c|c|c|c|c|}
\hline \multirow[t]{2}{*}{ Variables } & \multirow{2}{*}{$\begin{array}{c}\text { C. crepidioides } \\
\text { leaf meal } \\
\text { (CLM) }\end{array}$} & \multicolumn{4}{|c|}{ Experimental diets } \\
\hline & & Control & CLM5 & CLM10 & CLM15 \\
\hline Crude protein & $272.9 \pm 0.21$ & $304.5 \pm 0.13$ & $304.1 \pm 0.15$ & $305.1 \pm 0.22$ & $306.3 \pm 0.22$ \\
\hline Crude lipid & $28.8 \pm 0.12$ & $70.7 \pm 0.08$ & $68.0 \pm 0.18$ & $65.2 \pm 0.13$ & $66.5 \pm 0.25$ \\
\hline $\begin{array}{l}\text { Nitrogen free } \\
\text { extract (NFE) }\end{array}$ & $416.8 \pm 0.25$ & $472.9 \pm 0.37$ & $473.8 \pm 0.24$ & $473 \pm 0.24$ & $472.0 \pm 0.11$ \\
\hline Crude fibre & $90.1 \pm 0.22$ & $65.5 \pm 0.19$ & $68.7 \pm 0.20$ & $70.7 \pm 0.11$ & $73.0 \pm 0.11$ \\
\hline Ash & $191.2 \pm 0.24$ & $86.4 \pm 0.15$ & $84.9 \pm 0.12$ & $87.2 \pm 0.14$ & $82.0 \pm 0.09$ \\
\hline $\begin{array}{l}\text { Digestibleenergy } \\
\left(\mathrm{MJ} \mathrm{Kg}^{-1}\right)\end{array}$ & $14.14 \pm 0.06$ & $16.78 \pm 0.03$ & $16.73 \pm 0.01$ & $16.67 \pm 0.04$ & $16.76 \pm 0.05$ \\
\hline
\end{tabular}

Table.3 Anti-nutritional factors of unprocessed Crassocephalum crepidioides leaf meal and processed Crassocephalum crepidioides leaf meal (CLM)

\begin{tabular}{|l|c|c|}
\hline Anti-nutritional factors & $\begin{array}{c}\text { Unprocessed } C . \\
\text { crepidioides leaf meal }\end{array}$ & $\begin{array}{c}\text { Processed/detoxified } \\
\text { C. crepidioides leaf meal } \\
\text { (CLM) }\end{array}$ \\
\hline Cyanide $\left(\mathrm{mgHCN} \mathrm{Kg}^{-1}\right)$ & 11.85 & 2.83 \\
\hline Phytic acid $\left(\mathrm{g} \mathrm{Kg}^{-1)}\right.$ & 2.14 & 1.13 \\
\hline Saponin $\left(\mathrm{g} \mathrm{Kg}^{-1)}\right.$ & 0.43 & 0.19 \\
\hline Oxalate $\left(\mathrm{g} \mathrm{Kg}^{-1)}\right.$ & 0.30 & 0.17 \\
\hline Tannin $\left(\mathrm{g} \mathrm{Kg}^{-1)}\right.$ & 0.09 & 0.03 \\
\hline
\end{tabular}

Table.4 Physico-chemical parameters of water during the experimental period of 60 days for different experimental groups

\begin{tabular}{|r|l|l|}
\hline SI. No. & Parameters & Ranges \\
\hline 1. & Temperature & $24.8-28.5^{\circ} \mathrm{C}$ \\
\hline 2. & $\mathrm{pH}$ & $7.2-8.3$ \\
\hline 3 & Dissolved oxygen & $5.6-7.1 \mathrm{mg} / \mathrm{L}$ \\
\hline 4 & Total hardness & $137-198 \mathrm{mg} / \mathrm{L}$ \\
\hline 5 & Ammonia & $0.01-0.06 \mathrm{mg} / \mathrm{L}$ \\
\hline 6. & Nitrite & $0.008-0.02 \mathrm{mg} / \mathrm{L}$ \\
\hline 7. & Nitrate & $0.96-1.5 \mathrm{mg} / \mathrm{L}$ \\
\hline
\end{tabular}


Table.5 Growth performance, nutrient utilization, survival of Labeo rohita fingerlings fed with different experimental diets

\begin{tabular}{|l|c|c|c|c|c|c|c|}
\hline & \multicolumn{7}{|c|}{ Parameters } \\
& $\begin{array}{c}\text { Weight gain } \\
(\%)\end{array}$ & SGR $(\%)$ & FCR & PER & $\begin{array}{c}\text { Survival } \\
(\%)\end{array}$ & HSI & ISI \\
\hline Control & $128.79 \pm 3.11$ & $1.38 \pm 0.02$ & $1.85 \pm 0.04$ & $1.78 \pm 0.04$ & 100 & $1.15 \pm 0.07$ & $4.36 \pm 0.03$ \\
\hline CLM5 & $124.02 \pm 5.69$ & $1.34 \pm 0.04$ & $1.92 \pm 0.06$ & $1.71 \pm 0.05$ & 100 & $1.21 \pm 0.03$ & $4.40 \pm 0.09$ \\
\hline CLM10 & $116.74 \pm 4.67$ & $1.29 \pm 0.03$ & $1.96 \pm 0.04$ & $1.67 \pm 0.02$ & 100 & $1.19 \pm 0.02$ & $4.51 \pm 0.10$ \\
\hline CLM15 & $114.27 \pm 7.58$ & $1.26 \pm 0.06$ & $2.04 \pm 0.11$ & $1.61 \pm 0.08$ & 100 & $1.13 \pm 0.08$ & $4.29 \pm 0.08$ \\
\hline
\end{tabular}

Values in the same column were not significantly different $(\mathrm{P}<0.05)$. Data expressed as mean $\pm \mathrm{SE}(\mathrm{n}=3)$

SGR (\%): Specific growth rate, FCR: Feed conversion ratio, PER: Protein efficiency ratio,

HSI: Hepatosomatic index, ISI: Intestinal somatic index

Table.6 Proximate composition of the whole body of Labeo rohita fingerlings of different experimental groups (\% wet wt. basis $\pm \mathrm{SE}$ )

\begin{tabular}{|l|c|c|c|c|}
\hline \multirow{2}{*}{ Variables } & \multicolumn{4}{|c|}{ Experimental groups } \\
\cline { 2 - 5 } & Control & CLM5 & CLM10 & CLM15 \\
\hline Moisture & $73.94 \pm 0.19$ & $73.24 \pm 16$ & $73.56 \pm 18$ & $73.76 \pm 20$ \\
\hline Crude protein & $15.87 \pm 20$ & $15.75 \pm 21$ & $15.84 \pm 23$ & $15.60 \pm 19$ \\
\hline Crude lipid & $5.51 \pm 19$ & $5.85 \pm 22$ & $5.48 \pm 19$ & $5.86 \pm 27$ \\
\hline Ash & $2.80 \pm 13$ & $3.05 \pm 25$ & $2.56 \pm 21$ & $2.48 \pm 18$ \\
\hline
\end{tabular}

Values in the same row were not significantly different $(\mathrm{P}<0.05)$. Data expressed as mean $\pm \mathrm{SE}(\mathrm{n}=3)$

Certain underexploited nutritious plant can be utilised effectively once the presence of antinutritional factors is removed. Various methods of blanching, squeezed, drying to reduce anti-nutritional factors of Crassocephalum crepidioides (Nupo et al., 2013). Steaming, sun-drying, shredding reduce cyanide and phytate in cassava leaves (Abok et al., 2016, Montagnac et al., 2008). In the present study, Crassocephalum crepidioides leaf meal (CLM) was treated with step by step detoxification process such as steam blanching, squeezing, drying, shredding/gringding and the results obtained after analysis showed that the amount of antinutritional factor present in CLM is detoxified to safe level which can be tolerated by a monogastric animal including human. This is comparable with the report of (Nupo et al., 2013, Ilelaboye et al., 2013) which proved Crassocephalum crepidioides can be detoxified to a safe level. Tagwireyi et al., (2008) also reported that steamed treated diets showed better growth performance than boiled diets in Nile tilapia fry.

The in vitro protein digestibility of CLM was $75.31 \%$ which was higher than the in vitro digestibility of cotton seed cake and rubber seed cake in Labeo rohita $73.61 \%$ and $66.54 \%$ respectively (Hasnat et al., 2015). Ali et al., 2009 also reported that in vitro digestibility of soybean meal was $79.41 \%$ in Puntiusgonionotus. A feeding trial was conducted on Labeo rohita fingerlings feed with processed/detoxified Crassocephalum crepidioides leaf meal (CLM). All the physical-chemical parameters in the water remained within the range recommended for fish culture (Boyd, 1990) which suggests that water quality do not cause any physiological stress to the fish. 
In the present study, no significant variation was observed in the growth performance of the fish fed CLM in replacement for soybean meal. The lack of differences in the PER and FCR indicate that the CLM was well digested and utilized by the fish. This observation showed a good congruence with recent studies of Tiamiyu et al., (2016) who reported that Moringa leaf meal can substitute $50 \%$ of soybean meal in the diet of Oreochromisniloticus without affecting the growth and nutrient utilisation. Kasiga et al., (2014) also observed no significant difference in Oreochromisniloticus fed Moringaoleifera leaf meal or Leucaenaleucocephala leaf meal replacing up to $30 \%$ of the soybean meal protein despite lower nutrient availability compared with soy diet. Similar results were also shown by Mohapatra et al., (2015) that a diet consisting of Eichhornia crassipes meal up to $40 \%$ content could be used as a replacement for fish meal in diet formulation for common carp fry (Mohapatra 2015).

The presence of anti-nutritional factors in plant-based diets is one of the reasons for the reduction of feed intake, nutrient absorption and growth retardation in fish due to unpleasant tastes and poor feed acceptability (Francis and Becker, 2001). However, the inclusion of CLM in the diets of the fish in this study did not cause any significant difference in the whole body composition and survival of the fish in various treatments groups. This is in agreement with Hussein et al., (2016) who reported that whole body composition and survival of Nile Tilapia were not affected by the dietary replacement of yellow corn with sorghum meal.

The HIS and ISI values did not differ significantly among the fish of different experimental groups, which is in agreement with the study of Mishra et al., (2017), who observed that $L$. rohita fed Westleopsis prolifica, algae as a major dietary ingredients showed no significant differences in HSI. Phulia et al., (2017) also found no significant differences in HSI and ISI of L. rohita fed fermented Jatropha kernel meal in replacement of soybean meal. This lack of differences in the HSI and ISI indicate that the physiological functions and survival of fish were not compromised as a result of feeding CLM.

Based on the observations in the present study, it is revealed that CLM is a rich plant protein source. Processed or detoxified CLM showed a considerable value of in-vitro digestibility and no significant reduction in the feed consumption of L. rohita. Feeding processed or detoxified CLM upto $15 \%$ replacement of soybean meal showed improvement of the fish growth, no significant mortality and whole body composition suggesting its potential use in aquafeed. Therefore, CLM could replace possibly up to $15 \%$ of soybean without any detrimental effect in growth and survival of the fish and become a promising alternative plant protein source in search for sustainable and economically viable ingredients for aquafeed industries.

\section{Acknowledgement}

The authors would like to thank the Director, Central Institute of Fisheries Education, Mumbai for providing infrastructure facilities required in the research work. The authors wish to extend their gratitude to the ICAR for financial support.

\section{References}

Abok, E.O., Ooko, G.A., Okoth, M.W. 2016. Cassava chips quality as influenced by cultivar, blanching time and slice thickness. Afr. J. food Agri. Nut. Dev., 16: 11457-11476. 
Adjatin, A., Dansi, A., Badoussi E., Loko, Y.L., Dansi, M., Azokpota, P., Gbaguidi, F., Ahissouh, Akoègninou, A., Akpagana K., and Sanni A. 2013. Proximate, mineral and vitamin $\mathrm{C}$ composition of vegetable Gbolo [Crassocephalum rubens (Juss. Ex Jacq.) S. Moore and C. crepidioides (Benth.) S. Moore] in Benin." Int. J.Curr. Microbiol App. Sci., 2: 1-13.

Ali, H., Chisty, M.A.H., Saha, A., Alam, M.S., Shariful, M.I. 2009. Determination of In vitro protein digestibility of different feed ingredients Puntius gonionotus (Thai sarputi). $J$. Agro. for Environ., 3: 65-68.

AOAC. 1984. Official Methods of Analysis 14th ed. Association of official Analytical Chemists.

AOAC.1975. Association of Official Analytical Chemist.

APHA (American Public Health Association). 1998. Standard methods for examination of water and waste water, 15th edn. APHA, Washington.

Boyd, C. E. 1990. Water quality in ponds for Aquaculture. Birmingham Publishing, London, UK, pp. 482.

Chinma, C.E., and Igyor, M.A. 2007. Micronutrients and anti-nutritional contents of selected tropical vegetables grown in Southeast, Nigeria. Niger Food J. 25(1): 111-116.

Coffey, D., Dawson, K., Ferket, P., Connolly, A. 2016. Review of the feed industry from a historical perspective and implications for its future. J. Appl. Anim. Nutr. 4 (3): 1-11.

Dairo, F.A.S., Adanlawo, I.G. 2007.Nutritional quality of Crassocephalum crepidioides and Seneciobiafrae. Pak. J. Nut., 6: 35-39.

Day, R.A., Underwood A.L. 1986. Quantitive analysis 5th ed. Prentice. Hall publication p.701.
Etong, D.I., Abbah, E.A. 2014.Estimation of nutrients and anti-nutrients components of three Nigerian leafy vegetables. Food Sci. Qual. Manag. 2014; 33: 10-20.

FAO. 2013. Food Outlook: Biannual report on global food markets (June). Rome: FAO.

Francis, G.M., Becker, H.P.S. 2001. Antinutritional factors present in plant derived alternate fish feed ingredients and their effects in fish. Aquacult. 199: 197-227.

Gangte, H.E., Thoudam, N.S., Zomi, G.T. 2013. Wild edible plants used by the Zou tribe in Manipur, India. Inter. J. Sci. Res., 3: 1-8.

Hanglem, A., Thokchom, R., Singh, S.S., Thokchom, J. 2017. Harnessing the indigenous knowledge base associated with horticultural enterprise for sustainable development of north eastern state, Manipur, India. Inter. J. Curr. Microbial. App Sci., 6(10): 32663274.

Hanssen, O.K. 2003. Soya is no soya: (soya proteins for feed products). Feed Int., 23:14-18.

Hasnat, A., Pal, A.K., Sahu, N.P. 2015. Electron beam irradiation on Aquafeed: Effect on growth and in vitro protein digestibility in Labeo rohita and Clariusbatrachus. Adv. Appl. Sci. Res., 6: 97-102.

Heim, E. 2015. Flora and Vegetation of Bali Indonesia: An Illustrated Field Guide. Asteraceae. Books on Demand.

Hussein, M.S., Abd., E.A., Ali, M.W., Elazim A.E.M. 2016. Effect of sorghum replacement and probiotic on growth performance and feed utilization of the Nile Tilapia (Oreochromis niloticus). Egypt. J. Aquat. Biol. Fish., 20: 113121.

Ihekorunye, A.I., and Ngoddy, P.O. 1985. Integrated Food Science and technology 
or tropics. Macmillian publisher. London, 257-264.

Ilelaboye, N.O.A., Amoo, I.A., Pikuda, O.O., 2013. Effect of cooking methods on mineral and anti-nutrient composition of some green leafy vegetables. Arch. Appl. Sci. Res., 5: 254-260.

Indriasari, Y., Wignyanto, Kumalaningshih, S. 2016. Effect of blanching on saponins and nutritional content of Moringa leaves extract. J. Food. Res., 5: 55-60.

Kasiga, T., Chen, R., Sink, T., Lochmann, R. 2014. Effects of reduced soybean-meal diets containing Moringaoleifera or Leucaenaleucocephala leaf meals on growth performance, plasma lysozyme, and total instestinal proteolytic enzyme activity of juvenile Nile tilapia (Oreochromis niloticus), in outdoor tanks. J. World Aquacult. Soc., 45: 508522.

Makkar, H.P.S., Blummel, M., Borowy, N.K., Becker, K. 1993.Gravimetric determinations of tannins and their correlations with chemical and protein precipitation methods. J. Sc. Food Agricult., 61: 161 - 165.

Mishra, K., Patra, S.K., Samantaray, K. 2017. Effect of algae based diets on growth performance, body composition and fatty acid profile of Indian Major Carp, Rohu (Labeo rohita, Hamilton 1822). J. Fish. Sci., 11 (3): 005-016.

Mohapatra, S.B. 2015. Utilization of water hyacinth (Eichhorniacrassipes) meal as partial fish protein replacement in the diet of Cyprinuscarpio fry. Euro. J. Exp. Bio., 5: 31-36.

Montagnac, J.A., Davis, C.R., Tanumihardjo, S.A. 2008.Processing techniques to reduce toxicity and antinutrients of cassava for use as a staple food. Compr. Rev. Food Sci. Food Saf., 8: 17-27.

Ng, X.N., Chye, F.Y., Mohd, I.A. 2012. Nutritional profile and antioxidative properties of selected tropical wild vegetables. Int. Food Res. J., 19: 14871496.

Nupo, S.S., Onigbogi, I.O., Akinlotan, J.V., Ilori, O.A. 2013. Effect of different processing methods on the nutrients and antinutrient composition of Seneciobiafrae, Crassocephalum crepidiodes and Solanumnigrum consumed in south west Nigeria. Am. J. Food Nut., 3: 147-154.

Oguntona, T, Oguntona, C.R.B., Williams L. 1989. Survey of food and nutrient intake of kanuri of Borno, Niger. Savanna., 10: 86-91.

Peisker, M. 2001.Manufacturing of soy protein concentrate for animal nutrition. Cahiers Options Mediterraneennes. 3. Conference of Feed Manufactures of the Mediterranean, Reus (Spain), 54: 103107.

Phulia, V., Sardar, P., Sahu, N.P., Fawole, F.J., Shamna, N., Gupta, S. 2017. Substitution of soybean meal with fermented Jatropha kernel meal: effect on growth performance, body composition, and metabolic enzyme activity of Labeo rohita. Fish Physio. Biochem., 44: 475-487.

Puycha, K., Yuangsoi, B., Charoenwattanasak, S., Wongmaneeprateep, S., Niamphithak, P., Wiriyapattanasub, P. 2017. Effect of moringa (Moringa oleifera) leaf supplementation on growth performance and feed utilization of Bocourti's catfish (Pangasiusbocourti). Agri. Nat. Res., 51: 286-291.

Rajkumari, R., Singh, P.K., Das, A.K., Dutta, B.K. 2013.Ethnobotanical investigation of wild edible and medicinal plants used by the Chiru Tribe of Man., India. Pleione., 7 :167-174.

Storebakken, T., Refstie, S., Ruyter, B. 2000. Soy products as fat and protein sources in fish feeds for intensive 
aquaculture. In: Drackly, J.K. (Ed.), Soy in Anim. Nutri., Feder. Of Anim. Sci. Soc, Savoy, IL, pp. 127-170.

Tagwireyi, T., Mupangwa, J.F., Jepsen, J., Mwera, P. 2008.Effect of feeding Moringa oleifera leaf meal on the growth performance of Oreochromis niloticus fry. $3^{\text {rd }}$ ICAT Proceedings, Part 5.

Tamang, J.P. 2009. Himalayan fermented foods: microbiology, nutrition, and ethnic values. Book, 33-34.

Thokchom, S., Ningombam, D.S., Chanchal, Ch., Singh, H.B. 2015.Folk-medicare system of Chakpa community of Andro Village of Manipur in Northeast India. Am. J. Ethnomed., 2: 239-264.

Tiamiyu, L.O., Okomoda, V.T., Aende, A. 2016. Growth performance of
Oreochromis niloticus fingerlings fed Moringa oleifera leaf as replacement for soybean meal. J. Aquacult. Eng. Fish. Res., 2: 61-66.

Vaintraub, I.A., Lapteva, N.A. 1998.Colorimetric determination of phytate in unpurified extracts of seeds and the products of their processing. Anal. Biochem., 175(1): 227-230.

World Bank: Fish to 2030. 2013. Prospects for Fisheries and Aquaculture. World Bank Report, Number 83177- GLB.

Yaméogo, C.W., Bengaly, M.D., Savadogo, A., Nikiema, P.A., Traore, S.A. 2011. Determination of chemical composition and nutritional values of Moringa oleifera leaves. Pak. J. Nut., 10 (3): 264-268.

\section{How to cite this article:}

Khinlak Gangmei, Kamal Kant Jain, Narottam Prasad Sahu, Ashutosh Dharmendra Deo and Kundan Kumar. 2018. Effects of Replacing Soybean Meal with Crassocephalum crepidioides leaf Meal on Growth, Nutrient Utilisation and Whole Body Composition of Labeo rohita Fingerlings. Int.J.Curr.Microbiol.App.Sci. 7(09): 804-816. doi: https://doi.org/10.20546/ijcmas.2018.709.096 